\title{
The Habit Of Using Blankets Or Sleepwear Uncompletely At Night As A Risk Factor For Filariasis In Primary School-Aged Children
} Kebiasaan Tidak Menggunakan Selimut/Pakaian Lengkap Sewaktu Tidur Malam Sebagai Faktor Risiko Terinfeksi Filariasis Pada Anak Usia Sekolah Dasar

Ikrimah Nafilata ${ }^{1}$ dan Praba Ginandjar ${ }^{2}$

\begin{abstract}
Filariasis is caused by 3 species of filarial worms and is transmitted by the Culex quinquefasciatus mosquito. Pekalongan Regency is an endemic filariasis area with an Mf rate of $>1 \%$. The prevalence of filariasis in primary school children is $1.98 \%$ in Tirto and Buaran Subdistricts, the behavior of using blankets / complete clothing while sleeping at night in children needs to be studied further to prove the risk factors for filariasis. This study is a cross sectional analytic study, to prove the use of blankets / complete clothing during night sleep as a risk factor for the incidence of filariasis, using purposive samples of 84 samples of primary school age children in grades $3,4,5,6$. The stage of this research is finger blood screening using Immunochromatographic Card Test (ICT), indept interview and direct observation in Tirto and Buaran Subdistricts of Pekalongan Regency. The results of screening 17 positive and 67 negative filariasis were obtained. The results of the analysis using Chi Square did not use blankets / complete clothing while sleeping at night, $\mathrm{p}=0,000$ and $\mathrm{POR}=10,967$ (95\% Cl: 2,837-42,400). Not using mosquito nets when sleeping at night $\mathrm{p}$ value $=0.022$ and $\mathrm{POR}=4.527(95 \% \mathrm{Cl}: 1.335-15.3353)$. The habit of playing in the open space / place of breeding / resting vector is obtained $p=0.830$ and POR $=1.383$ (95\% Cl: 0.401-4.764). Not using blankets / complete clothes while sleeping at night and not using mosquito nets while sleeping at night is a possible risk factor for filariasis in primary school-aged children.
\end{abstract}

Keywords: Filariasis, child behavior.

\footnotetext{
Afiliasi Penulis

1 | Prodi D3 Teknologi Transfusi Darah STIKes Guna Bangsa Yogyakarta

2 | Fakultas Kesehatan Masyarakat Universitas Diponegoro Semarang

Korespondensi kepada

I. Nafilata

nafilataikrimah@gmail.com
} 


\section{Intisari}

Filariasis disebabkan oleh 3 spesies cacing filaria dan ditularkan oleh nyamuk Culex quinquefasciatus. Kabupaten Pekalongan merupakan daerah endemis filariasis dengan $\mathrm{Mf}$ rate $>1 \%$. Prevalensi kejadian filariasis pada anak usia sekolah dasar 1,98\% di Kecamatan Tirto dan Buaran, perilaku penggunaan selimut/ pakaian lengkap sewaktu tidur malam pada anak perlu dipelajari lebih lanjut untuk membuktikan faktor risiko kejadian filariasis. Penelitian ini merupakan penelitian Cross Sectional analitik, untuk membuktikan penggunaan selimut/pakaian lengkap sewaktu tidur malam sebagai faktor risiko kejadian filariasis, dengan menggunakan sampel purposif sebanyak 84 sampel anak usia sekolah dasar kelas 3, 4, 5, 6. Tahap penelitian ini skrining darah jari menggunakan Immunochromatographic Card Test (ICT), indept interview dan observasi langsung di Kecamatan Tirto dan Buaran Kabupaten Pekalongan. Berdasarkan hasil skrining didapatkan 17 positif dan 67 negatif filariasis. Hasil analisis menggunakan Chi Square tidak menggunakan selimut/pakaian lengkap sewaktu tidur malam didapatkan nilai $p=0,000$ dan POR $=10,967(95 \% \mathrm{Cl}: 2,837-42,400)$. Tidak menggunakan kelambu sewaktu tidur malam didapatkan nilai $p=0,022$ dan $\mathrm{POR}=4,527(95 \% \mathrm{Cl}: 1,335-15,353)$. Kebiasaan bermain di ruang terbuka/tempat perindukan/istirahat vektor didapatkan nilai $p=0,830$ dan $P O R=$ 1,383 (95\% Cl : 0,401-4,764). Tidak menggunakan selimut/pakaian lengkap sewaktu tidur malam dan tidak menggunakan kelambu sewaktu tidur malam dimungkinkan merupakan faktor risiko kejadian filariasis pada anak usia sekolah dasar.

Kata Kunci : Filariasis, Perilaku anak.

\section{Pendahuluan}

Filariasis adalah penyakit yang disebabkan oleh infeksi cacing nematoda berupa cacing filaria, yang terdiri dari tiga spesies yaitu Wuchereria bancrofti, Brugia malayi dan Brugia timori. Filariasis ditularkan oleh nyamuk Culex quinquefasciatus. ${ }^{[1]}$ Data akumulasi jumlah kasus klinis filariasis di Indonesia dari tahun 2010 sampai dengan 2014 sebanyak 14.932 kasus meningkat dari tahun sebelumnya yaitu tahun 2013 sebanyak 12.714 kasus klinis filariasis. ${ }^{[2]}$ Secara kumulatif, jumlah kasus Filariasis di Provinsi Jawa Tengah pada tahun 2013 sebanyak 583 penderita lebih banyak dibanding tahun 2012 (565 penderita) dan sampai dengan tahun 2014 tercatat mencapai 590 kasus. ${ }^{[3]}$

Kabupaten Pekalongan merupakan salah satu daerah endemis filariasis di Jawa Tengah dengan angka mikrofilaria >1\%. Data pada tahun 2014 menyebutkan sebaran kasus kronis sebanyak 66 kasus filariasis, meningkat dibandingkan tahun 2013 yaitu 57 kasus. ${ }^{[4]}$ Penelitian sebelumnya di Kabupaten Pekalongan (Kecamatan Tirto dan Buaran) pada tahun 2015, menyebutkan bahwa terdapat 15 positif terinfeksi filariasis Wuchereria bancrofti berdasarkan deteksi Circulating Filarial
Antigen (CFA) pada anak-anak usia sekolah dengan prevalensi $1,98 \%$. Penelitian tersebut dikaitkan dengan status mikronutrien (vitamin A dan vitamin E) pada anak-anak usia sekolah yang terdeteksi positif filariasis Wuchereria bancrofti dan paling banyak ditemukan pada Kecamatan Tirto. ${ }^{[5]}$

Kasus filariasis pada anak diketahui karena antibodi antifilaria pada kategori anak-anak rendah dan pada umumnya infeksi filariasis pada populasi anak-anak jarang mendapat perhatian/ terabaikan. ${ }^{[6,7]}$ Faktor risiko filariasis pada anak di Kabupaten Pekalongan perlu diteliti lebih lanjut, terutama tentang perilaku pada anak. Perilaku yang akan diteliti antara lain kebiasaan anak usia sekolah yang tidur tidak menggunakan pakaian lengkap, kebiasaan penggunaan kelambu, kebiasaan bermain di ruang terbuka atau lingkungan tempat istirahat/ perkembangbiakan vektor.

\section{Metode}

Penelitian ini merupakan penelitian Observasional analitik dengan desain Cross Sectional, menggunakan metode survei melalui dua tahap, yaitu pemeriksaan darah jari pada anak usia sekolah dasar kelas 3, 4, 5, 6 menggunakan 
Immunochromatographic Card Test (ICT) dan wawancara terstruktur beserta observasi langsung. Lokasi penelitian berada pada dua kecamatan di Kabupaten Pekalongan, yaitu Kecamatan Tirto yang terdiri dari Desa Tegaldowo, Kranding, Mulyorejo dan Karangjompo, serta Kecamatan Buaran yaitu Desa Paweden.

Sampel diambil secara purposif dengan besar sampel minimal sebesar 72 sampel, sampel di lapangan dalam penelitian ini sebanyak 84 sampel anak usia sekolah dasar. Berdasarkan pemeriksaan darah jari ditemukan 17 positif filariasis dari 84 sampel. Waktu penelitian dimulai pada bulan April minggu ketiga sampai dengan bulan Juni minggu kedua tahun 2016.

Data Faktor Risiko Filariasis pada anak usia sekolah dasar diambil melalui wawancara terstruktur menggunakan kuesioner pada 84 sampel baik yang positif filariasis maupun negatif filariasis. Analisis data menggunakan Chi Square dengan tingkat kepercayaan $95 \%$ dan analisis multivariat menggunakan Regresi Logistik.

\section{Hasil \& Pembahasan}

\section{Analisis Inferensial}

Analisis bivariat/inferensial digunakan untuk membuktikan variabel bebas (independent) yang terbukti sebagai faktor risiko filariasis pada anak usia sekolah dasar. Uji statistik menggunakan Chi Square dengan tingkat kepercayaan 95\%. Hasil analisis secara lengkap disajikan dalam Tabel 1.
Variabel Penggunaan selimut/pakaian lengkap sewaktu tidur malam mempunyai nilai $p=0,000$ dengan nilai $\mathrm{POR}=10,967(95 \% \mathrm{Cl}: 2,837-42,400)$. Variabel Penggunaan kelambu sewaktu tidur malam mempunyai nilai $p=0,022$ dengan nilai POR $=4,527(95 \% \mathrm{Cl}: 1,335-15,353)$. Variabel Kebiasaan bermain di ruang terbuka/tempat perindukan/ istirahat vektor mempunyai nilai $p=0,830$ dengan nilai POR $=1,383(95 \% \mathrm{Cl}: 0,401-4,764)$.

Berdasarkan hasil pemeriksaan darah jari menggunakan Immunochromatographic Card Test (ICT) dari 84 sampel anak usia sekolah dasar didapatkan 17 positif filariasis dan 67 negatif filariasis. ICT mempunyai sensitivitas $51,7 \%$ dan spesifitas $94,8 \%$, dengan false negative sebesar $14,5 \%{ }^{[10]}$

Hasil penelitian menyebutkan bahwa ada hubungan yang signifikan antara penggunaan selimut/pakaian lengkap sewaktu tidur malam dengan kejadian filariasis pada anak usia sekolah dasar, karena didapatkan nilai $p=0,000(p<0,05)$ dan nilai POR $=10,967(95 \% \mathrm{Cl}: 2,837-42,400)$, artinya bahwa secara perhitungan statistik anak usia sekolah yang tidak menggunakan selimut/pakaian lengkap sewaktu tidur malam berisiko 10,967 kali dan dimungkinkan merupakan faktor risiko kejadian filariasis. Hasil penelitian ini sejalan dengan penelitian sebelumnya bahwa ada hubungan yang signifikan antara kebiasaan menggunakan baju panjang dan celana panjang saat keluar rumah malam hari dengan nilai $p=$ 0,002 dan nilai $\mathrm{OR}=15,167 .{ }^{[8]}$ Namun

Tabel 1 | Ringkasan Analisis Inferensial

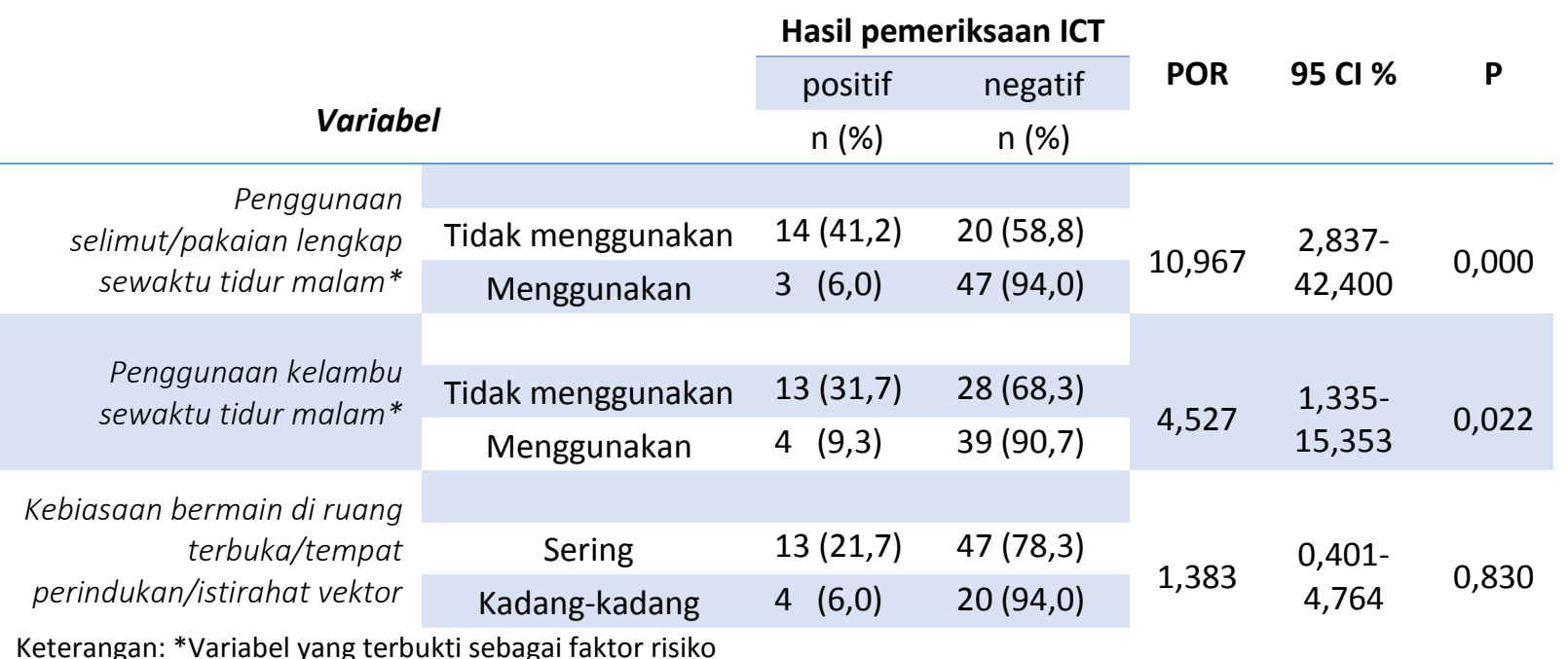




\section{Tabel 2 | Analisis Regresi Logistik}

\begin{tabular}{|c|c|c|c|c|c|}
\hline No & Faktor Risiko & Nilai B & POR & $95 \% \mathrm{Cl}$ & p \\
\hline 1 & $\begin{array}{l}\text { Penggunaan selimut/pakaian lengkap } \\
\text { sewaktu tidur malam }\end{array}$ & 2,401 & 11,030 & $\begin{array}{l}2,729- \\
44,589\end{array}$ & 0,001 \\
\hline 2 & Penggunaan kelambu sewaktu tidur malam & 1,519 & 4,567 & $\begin{array}{l}1,208- \\
17,264\end{array}$ & 0,025 \\
\hline & Konstanta & $-0,254$ & & & \\
\hline
\end{tabular}

perbedaannya adalah penelitian tersebut menyebutkan bahwa kebiasaan menggunakan baju panjang dan celana panjang saat keluar malam merupakan faktor risiko filariasis.

Penggunaan pakaian lengkap yang dapat menutupi seluruh anggota tubuh dapat menghindarkan dari gigitan nyamuk sebagai vektor filariasis, artinya tidak ada anggota tubuh yang tidak tertutup dan bisa menjadikan kontak dengan vektor filariasis, sehingga dapat terjadi kejadian filariasis.

Ada hubungan yang signifikan antara penggunaan kelambu sewaktu tidur malam dengan kejadian filariasis pada anak usia sekolah dasar, karena didapatkan nilai $p=0,022(p<0,05)$ dan nilai POR $=4,527 \quad(95 \% \mathrm{Cl}: 1,335-15,353)$ dan dimungkinkan merupakan faktor risiko filariasis pada anak usia sekolah, sesuai dengan hasil penelitian terdahulu yang menyebutkan bahwa pemakaian kelambu merupakan salah satu faktor risiko kejadian filariasis di Kota Pekalongan dengan nilai OR $=6,923(95 \% \mathrm{Cl}: 1,900-25,227) .{ }^{[9]}$ Begitu pula hasil penelitian yang lain menyebutkan hal yang sama bahwa pemakaian kelambu merupakan faktor risiko kejadian filariasis di Kabupaten Parigi Moutong Sulawesi Tengah dengan nilai OR $=9,4$ (95\% Cl : 2,969-29,296). ${ }^{[11]}$

Penggunaan kelambu pada waktu tidur malam hari merupakan salah satu cara untuk melindungi diri (Alat Pelindung Diri) dari gigitan nyamuk baik pada orang dewasa maupun pada anak-anak, dimana pada penelitian sebelumnya disebutkan aktivitas menggigit nyamuk Culex quinquefasciatus di dalam rumah dimulai sejak sore hari dan terus ditemukan sepanjang malam hingga pagi hari, dengan 3 puncak kepadatan yaitu pukul 20.0021.00, pukul 22.00-23.00 dan pukul 02.00-03.00. ${ }^{[12]}$ Seperti yang telah disebutkan bahwa pada usia anak-anak cenderung tidak menyukai pemakaian APD dikarenakan adanya berbagai alasan yang berhubungan dengan kenyamanan, sehingga responden anak-anak yang tidak menggunakan kelambu sewaktu tidur malam dapat lebih mudah untuk terjadi kontak dengan vektor filariasis.

Ketiga variabel tersebut yang menjadi kandidat dalam analisis multivariat regresi logistik yaitu Penggunaan selimut/ pakaian lengkap sewaktu tidur malam dan Penggunaan kelambu sewaktu tidur malam, karena nilai $p<0,25$.

\section{Analisis Multivariat}

Analisis multivariat dalam penelitian ini menggunakan uji regresi logistik, didapatkan hasil Analisis Regresi logistik variabel Penggunaan selimut/pakaian lengkap sewaktu tidur malam (tabel 2) dengan nilai $\mathrm{p}=0,001$ dengan nilai POR = $11,030 \quad(95 \% \mathrm{Cl}: 2,729-44,589)$. Variabel Penggunaan kelambu sewaktu tidur malam didapatkan nilai $\mathrm{p}=0,025$ dengan nilai $\mathrm{POR}=4,567$ (95\% Cl : 1,208-17,264). Probabilitas untuk terjadinya filariasis pada anak usia sekolah dasar apabila terdapat 2 faktor risiko tersebut yaitu sebesar $97,5 \%$.

\section{Kesimpulan}

Berdasarkan hasil penelitian, yang terbukti sebagai faktor risiko filariasis pada anak usia sekolah dasar yaitu tidak menggunakan selimut/pakaian lengkap sewaktu tidur malam dan tidak menggunakan kelambu sewaktu tidur malam merupakan faktor risiko filariasis.

Probabilitas untuk terjadinya filariasis pada anak usia sekolah dasar jika terdapat 2 faktor risiko tersebut yaitu sebesar $97,5 \%$. Variabel yang tidak terbukti sebagai faktor risiko filariasis pada anak usia sekolah yaitu kebiasaan bermain di ruang terbuka/tempat perindukan vektor/istirahat vektor. 


\section{Apresiasi}

Ucapan terima kasih kepada Bappeda dan Dinas Kesehatan Kabupaten Pekalongan, serta Puskesmas Tirto II dan Puskesmas Buaran yang telah memberikan izin untuk melaksanakan penelitian ini. Pihak sekolah SDN Tegaldowo, SDN Kranding, SDN Mulyorejo, SDN Karangjompo dan SDN Paweden yang telah membantu dan memfasilitasi untuk dilaksanakannya penelitian ini.

\section{Bibliografi}

1. Soedarto., 2009, Penyakit Menular di Indonesia, CV. Sagung Seto, Jakarta.

2. Kementrian Kesehatan Republik Indonesia, Profil Kesehatan Indonesia tahun 2014. Available from URL: http://www.depkes.go.id/resources/download/pusdati $\mathrm{n} /$ profil-kesehatan-indonesia/profil-kesehatanindonesia-2014.pdf

3. Dinas Kesehatan Provinsi Jawa Tengah, Profil Kesehatan Provinsi Jawa Tengah tahun 2014.

4. Dinas Kesehatan Kabupaten Pekalongan, Profil Kesehatan Kabupaten Pekalongan 2014. Bidang P2PPL, DKK Pekalongan, 2014.

5. Ginandjar P, Saraswati L.D., 2015, Identifikasi Circulating Filarial Antigen dan Mikronutrien yang Mempengaruhi Status Infeksi Wuchereria bancrofti, Seminar Nasional Fakultas Kesehatan Masyarakat Universitas Diponegoro, Semarang 2015.

6. Das, M.K., 2005, Lymphatic filariasis in young children : an immunological prospective, Annual Report 20052006 Regional Medical Research Center : Completed Study 2.

7. Figueredo-Silva J, Dreyer G. Bancroftian filariasis in children and adolescents: clinicalpathological observations in 22 cases from an endemic area. AnnTropMedParasitol2005;99:759-69. doi:10.1179/136485905X65170.

8. Amelia, R., 2014, Analisis Faktor Risiko Kejadian Penyakit Filariasis. Unnes Journal of Public Health.

9. Roziyah, Inna A. Hubungan Kondisi Fisik Lingkungan dan Perilaku Masyarakat dengan Kejadian Filariasis di Kelurahan Padukuhan Kraton Kota Pekalongan. Unnes Journal of Public Health; 2015.

10. Nguyen N.L., Plichart C, Esterre P., 1999, Assessment of Immunochromatographic Test for Rapid Lymphatic Filariasis Diagnosis. Journal Parasite, 6, 355-358.

11. Sunardi. 2006, Faktor Determinan yang Berhubungan dengan Kejadian Filariasis Malayi di Kecamatan Ampibabo Kabupaten Parigi Moutong Sulawesi Tengah. Perpustakaan Universitas Indonesia.
12. Ramadhani, T., 2008, Aktivitas Menggigit Nyamuk Culex quinquefasciatus di Daerah Endemis Filariasis Limfatik Kelurahan Pabean Kota Pekalongan Provinsi Jawa Tengah; Available from URL: HIPERLINK http://ejournal.litbang.depkes.go.id 